\title{
A Study on the Prospects and Potential Threats to the Hospitality Industry in India
}

\author{
Sherry Abraham* and C Rajesh Kumart
}

\section{Abstract}

The hospitality sector in India plays a vital role in terms of contributions to the economy of the country as an employment generator. The much wanted growth in the tourism sector of the country is in fact dependent on the growth and development of the hospitality sector. However, the ability of the hospitality sector to remain viable, profitable and competitive in the years to come will depend on its ability to foresee emerging trends and then capitalize on them. This is most essential, given that India, despite having high tourist potential, attracts far lesser foreign tourists as compared to smaller countries like Singapore, Thailand and Malaysia. This paper examines the key trends that are set to emerge in the hospitality sector in the country over the next decade. An exploratory methodology was used in this research including both theoretical and empirical methods. From the theoretical studies, it was found that these key trends include the growth of domestic tourism, the emergence of medical tourism as the key attraction in India, the development of tier 2 and tier 3 cities as important tourist hubs and the shift in tourist traffic away from luxury formats which have hitherto dominated the hotel industry and towards economically priced mid - level and budget hotels. However, there are several challenges that

* Assistant Professor, Department of Tourism Studies, Pondicherry University; sherryabrahamm@gmail.com

† Principal, SYNA International Academy of Hotel \& Tourism Management, Jhinjhari, Madhya Pradesh, India; rajleoni@gmail.com 
threaten the further growth and profitability of the Indian hospitality sector. There are manifold challenges confronting the hospitality sector in India. These include high attrition, high costs of operations, poor infrastructure, complex visa procedures, high rates of tax and government bureaucracy and red-tapism. This research includes a survey conducted amongst managers of several hotels in Bangalore city. The findings of this questionnaire corroborated the theoretical findings as well. These findings have been presented in this research. They clearly indicate that there does exist a tremendous potential for the development and growth of the hospitality sector in India and this will depend on the ability of the sector to successfully counter the many challenges that currently confront it. Based on this finding, suitable recommendations have also been made at the end of the paper. This research would meet its purpose if it succeeds in alerting the management of hotels across the country on the tremendous potential that exists for them in the years to come, the challenges that lie ahead and what needs to be done to suitably exploit and profit from these opportunities.

Keywords: Hospitality sector, Profitability, Trends, Potential threats, Prospects

\section{Introduction}

The hotel industry in India is a fast growing one. India is now one of the 'must see' tourist destinations in the world with the country projected to turn into the third most popular tourist destination by 2019 (Gibson, 2012). Post liberalization of 1990, India has turned into a major manufacturing and IT exports hub. India is projected to become the fifth most favoured business destination by 2020 (Gill and Gill, 2012). These two triggers, i.e. the growth in tourism and in business opportunities, have resulted in the doubling of the number of travelers to and within the country. While 10 million foreign tourists visited India in 2012, the number of domestic travellers alone number up to 350 million persons in that year (Rathod et al., 2013). 
This growth in tourism has resulted in the development of the hospitality sector as well. There are several indicators that the hospitality sector is all set to grow substantially over the next decade due to a few key drivers. These include the rise of business and medical tourism in India, an increase in the number of domestic tourists, the growth of tier 2 and 3 towns and of moderately priced mid - level and budget hotels, the entry of many international hotel brands and environmental sustainability. However, the exploitation of these key opportunities and drivers will depend on the ability of the Indian hotel sector to successfully counter the manifold challenges confronting the industry. These include the high costs of starting and operating hotels, high costs of utilities, completion, high attrition rates, lack of skilled manpower, government bureaucracy and lack of infrastructure. This research will explore whether these theoretical findings are in fact substantiated and validated by the hotel sector in India.

\section{Aims and Objectives}

- To study the trends in the hospitality sector in India

- To understand key challenges confronting the hospitality sector in India

- To validate these trends and challenges by conducting an interview of management in key hotel chains in India

\section{Literature Review}

Post the liberalization of the Indian economy in 1990, the tourism sector in India has grown by leaps and bounds. India is currently ranked $11^{\text {th }}$ in the list of the most attractive tourist destinations in the world for its natural beauty, art and culture and world heritage architectural sites (Adner, 2010). According to Gill and Gil (2012), by 2019 , India is projected to become the third most favoured travel destination and the fifth most favoured business destination in the world.

The development of tourism in India has also fuelled the growth of the hospitality sector. From just 120 hotels with 18160 rooms in 1995, India today boasts of nearly 800 hotels with about 100,000 
rooms (Rathod et al., 2013). This is the second largest number of hotels and rooms in the entire ASIPAC region. Moreover, there are over forty international hotel brands operating in the country today that are expected to add another 350 properties and another 100,000 rooms by 2015 (Thadani, 2012). According to Kulins (2011), the hotel industry alone contributed up to $\$ 2.1$ billion to the GDP of India over the period 2000 to 2010 and this is expected to increase to $\$ 51.4$ billion by 2019 . The industry employs about 150,000 persons (or $6.4 \%$ of the total workforce) currently and this is expected to increase to almost 10\% by 2019 (Marothia, 2010).

Several key trends have been projected to drive the hotel industry over the next decades which bring along with them some major challenges. According to Barot (2011), one of the most important driver is the surge in business tourism. The opening of the Indian economy in 1990, the growth of the IT industry in India, the possibilities of establishing cheap centers of production in India and the large untapped market presented by its 400 million strong middle and upper middle class has seen an increase in the number of foreign visitors who visit the country for business purposes. The growth of the domestic tourism is another key trend. Post the development of the economy and growth in disposable incomes there has been a surge in domestic visitors all across the country. From 250 million visitors in 2005, the number of domestic visitors grew to 400 million in 2009 and to 545 million in 2011 (Kulins, 2011). Hence there are a larger number of domestic tourists in India as compared to foreign tourists. This indicates that domestic tourism will be a major driver of tourism growth in India.

India is also emerging as the global hotspot for medical tourism. In fact medical tourism is the fastest growing sector within the hospitality sector in India today (Gibson, 2012). Elevated cost of treatments in the developed countries, particularly the USA and UK, has been forcing patients from such regions to look for alternative and cost-effective destinations to get their treatments complete. India represents the most prospective medical tourism market in the world (Gibson, 2012). Factors such as low cost, scale and range of treatments provided by India differentiate it from other medical tourism destinations. Furthermore, the growth in India's medical tourism market will be a boon for several 
associated industries, including hospital industry, medical equipment industry and pharmaceutical industry. According to Jogarathan and Tse (2011), with over 3,000 hospitals and around 726,000 registered practitioners catering to the needs of traditional Indian healthcare, India already accounts for $2.4 \%$ of the total worldwide medical tourism industry.

Another key trend is the shift towards mid-market and budget hotels. Traditionally, India has been associated with the development of luxury and upscale which hitherto accounted for $50 \%$ of all hotel rooms. However by 2012 , luxury hotels accounted for only $45 \%$ of all hotel rooms and this had further dropped to 43.7\% by August 2013 (Beech and Chadwick, 2012). This heralds the growth of mid-market and budget hotels and the consequent availability of lodging options across multiple price points which will further trigger the growth of domestic tourism. Another development is the growth of tourist activity in tier 2 and 3 cities. These are about 60 tier 2 and 3 towns located near major cities or tourist locations and have a population of about half a million (Berry, 2010). Improved infrastructure, better connectivity, improved commercial activity, the development of airports, roads and convention centres, development of business, medical and educational hubs in these centres account for the development of tourism in these towns. Another trend is the entry of leading global hotels chains which compete with established players in the Indian hotel sector. These include Starwood Hotels and Resorts, Accor, Zinc InVision and Lemon Tree. The incorporation of environment friendly practices in building and operating hotels is another emerging trend.

The Indian hotel industry is facing several challenges as well. There is a shortage of nearly 10,000 rooms in the country today (Gil and Gill, 2012). According to Krishnan (2010), the lack of skilled, trained manpower coupled with high attrition rates is another challenge. High cost of utilities including energy, water, electricity and very high rates of taxation impact profitability. India still does not have world class infrastructure such as airports, roads, taxi facilities, tour guides and travel managers. Cost of land typically accounts for $45 \%$ of total cost of construction (Page, 2011). Government bureaucracy and red tape necessitates obtaining almost 120 permits 
to open and operate hotels in India today (Kulins, 2011). In addition, according to Gee (2011), marketing the 'Incredible India' story requires more innovation and private sector participation.

It may be concluded from the above that while there exists great potential for the growth of the Indian tourist sector, taking advantage of this opportunity is dependent on overcoming significant hurdles as well.

\section{Methodology}

Quantitative methods used in this research included both deductive and inductive techniques. The deductive method involved study of secondary literature on the hotel industry in India and the possible emerging trends and challenges. This deductive study led to formulation of the literature review. The inductive method involved administration of an online questionnaire to 100 managers of 20 hotels in Bangalore city. The questionnaire was administered to 5 managers from each hotel. The respondents could answer the questionnaire on a four point Likert scale. The results of the questionnaire were summarized and analysed in Excel. The results of the analysis have been presented in graphical format. The main purpose of the questionnaire was to understand what in their opinion, did the managers consider to be the main emerging trends of the Indian hospitality industry and what they believed to be the key challenges confronting the sector today.

\section{Discussion and Analysis}

The respondents were first asked as to what they believed the main challenges confronting the hospitality sector in India to be. Table 1 summarizes their answers. 


\section{Government Signific}

\begin{tabular}{|c|c|c|c|c|c|c|}
\hline & 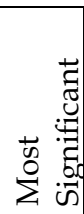 & 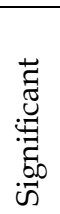 & 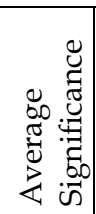 & Z & 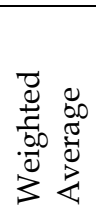 & Interpretation \\
\hline & 4 & 3 & 2 & 1 & & \\
\hline Competetion & 0 & 1 & 38 & 61 & 1.4 & No Significance \\
\hline $\begin{array}{l}\text { Government } \\
\text { Ineptitude }\end{array}$ & 0 & 56 & 39 & 5 & 2.5 & Significant \\
\hline High Prices & 74 & 26 & 0 & 0 & 3.7 & Most Significant \\
\hline Low tourist Traffic & 0 & 0 & 0 & 100 & 1.0 & No Significance \\
\hline The Recession & 0 & 0 & 0 & 100 & 1.0 & No Significance \\
\hline Lack of Infrastructure & 100 & 0 & 0 & 0 & 4.0 & Most Significant \\
\hline $\begin{array}{l}\text { Lack of Potential of } \\
\text { India as a tourist or } \\
\text { business destination }\end{array}$ & 0 & 0 & 0 & 100 & 1.0 & No Significance \\
\hline $\begin{array}{l}\text { Lack of skilled } \\
\text { manpower / high } \\
\text { attrition rates }\end{array}$ & 100 & 0 & 0 & 0 & 4.0 & Most Significant \\
\hline $\begin{array}{l}\text { High cost of land, high } \\
\text { cost of operations }\end{array}$ & 0 & 100 & 0 & 0 & 3.0 & Significant \\
\hline
\end{tabular}

Fig1: Challenges confronting the hospitality sector in India

It can be seen that the entire factors one would have assumed to be most challenging have in fact marked as not being significant challenges at all. These include competition, the recession and the possibility of low tourist footfalls and the lessening in the potential of India as a tourist destination. What in fact, have been marked as being significant challenges are high prices, lack of skilled manpower, high attrition rates, high cost of land and of operations, lack of infrastructure and government bureaucracy. These corroborate the findings of the literature review, where it was identified that while the hospitality sector of India theoretically at least has a bright future, this will depend on the ability of the sector to successfully tackle the aforementioned challenges.

This confidence in the hospitality sector amongst all respondents is manifested in the response to the second question summarized in Figure 2. 


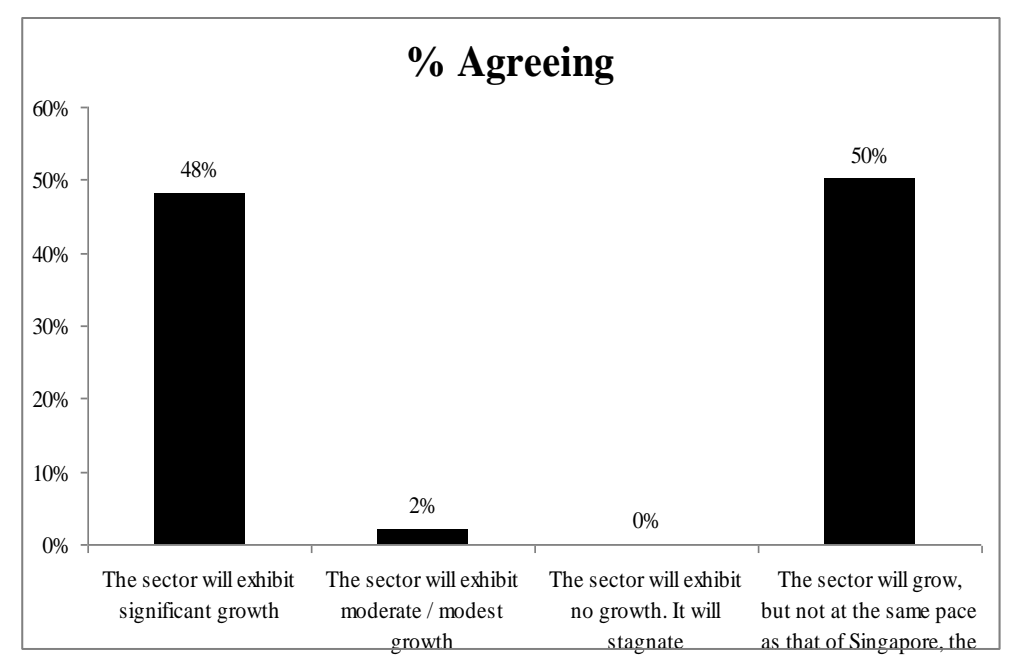

Fig 2: The Future of the Hospitality Sector in India

It can be seen from figure 2, that half the respondents believe that the hospitality sector in India has a very bright future. However, the other half believes that the sector will not grow at the same rate as that of such established tourist destinations as Singapore or UK. This is a veiled reference to the challenges confronting the sector in India and the dependence of the growth of the sector on its ability to counter these challenges.

One of the key findings of the literature review, is that business tourism is a fast growing category in India. The growth of Indian industry and the development of India as a global IT hub and the growth of large consumer markets in India have all contributed to the growth of business opportunities in the country, and all these attract a large number of business visitors.

\begin{tabular}{|l|c|c|c|}
\hline & $\begin{array}{c}\text { Business Tourism } \\
\text { is more than } \\
\text { leisure tourism }\end{array}$ & $\begin{array}{c}\text { Both business and } \\
\text { leusire tourism are } \\
\text { equally important }\end{array}$ & $\begin{array}{c}\text { Leisure tourism is } \\
\text { larger than } \\
\text { Business tourism }\end{array}$ \\
\hline $\begin{array}{l}\text { No customers } \\
\text { agreeing }\end{array}$ & 37 & 38 & 25 \\
\hline $\begin{array}{l}\text { Total number } \\
\text { of customers }\end{array}$ & 100 & 100 & 100 \\
\hline$\%$ Agreeing & $37 \%$ & $38 \%$ & $25 \%$ \\
\hline
\end{tabular}

Fig 3: Business Tourism versus Leisure Tourism 
As can be seen from figure 3, more than one third of all the respondents believe that business tourism has more potential than leisure tourism with another one third believing that business tourism is as important as leisure tourism.

Another finding of the literature review, is that India holds manifold attractions for potential tourists. These include adventure, sports, arts and culture, business, leisure, education and nature tourism. However, the rise in costs of medical expenses in Western countries and the relatively low costs of treatment in India coupled with the proliferation of quality healthcare centres in India have quickly transformed medical tourism into the number one attraction in India.

\begin{tabular}{|c|c|c|c|c|c|c|}
\hline & 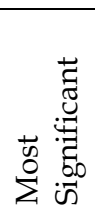 & 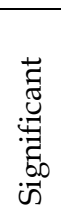 & 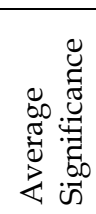 & 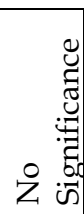 & 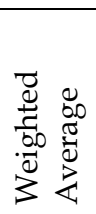 & Interpretation \\
\hline & 4 & 3 & 2 & 1 & & \\
\hline Adventure Tourism & 26 & 67 & 7 & 0 & 3.2 & Significant \\
\hline Sports Tourism & 0 & 0 & 67 & 33 & 1.7 & Average Significant \\
\hline $\begin{array}{l}\text { Arts and Culture } \\
\text { Tourism }\end{array}$ & 12 & 88 & 0 & 0 & 3.1 & Significant \\
\hline Business Tourism & 38 & 62 & 0 & 0 & 3.4 & Significant \\
\hline Leisure Tourism & 21 & 79 & 0 & 0 & 3.2 & Significant \\
\hline Medical Tourism & 100 & 0 & 0 & 0 & 4.0 & Most Significant \\
\hline $\begin{array}{l}\text { Educational } \\
\text { Tourism }\end{array}$ & 0 & 53 & 47 & 0 & 2.5 & Significant \\
\hline $\begin{array}{l}\text { Nature/Wildlife } \\
\text { Tourism }\end{array}$ & 29 & 71 & 0 & 0 & 3.3 & Significant \\
\hline
\end{tabular}

Fig 4: Popularity of Medical Tourism

This finding has been corroborated by the respondents from the hotels as well. While all forms of tourism have been deemed as being important, medical tourism has been accorded the most important and the sector with the greatest potential.

The gradual shift in centres of manufacture and consumption away from tier 1 cities and towards tier 2 and tier 3 cities, the proximity of these towns to big cities and to centres of culture and history, the development of infrastructure in these towns have all contributed to the growth of tourism potential here. From the literature review, 
it was identified that these towns hold the key for the development of hospitality sector in India over the next decade.

\begin{tabular}{|l|c|c|c|c|l|}
\hline & $\begin{array}{c}\text { Most } \\
\text { Preferred }\end{array}$ & Preferred & $\begin{array}{c}\text { Not } \\
\text { Preferred }\end{array}$ & $\begin{array}{c}\text { Weighted } \\
\text { Average }\end{array}$ & Interpretation \\
\cline { 2 - 4 } & 3 & 2 & 1 & & \\
\hline Mysore & 100 & 0 & 0 & 3.0 & Most Preferred \\
\hline Mumbai & 0 & 7 & 93 & 1.1 & Not Preferred \\
\hline Amravathi & 0 & 95 & 5 & 2.0 & Preferred \\
\hline Delhi & 0 & 0 & 100 & 1.0 & Not Preferred \\
\hline Agra & 100 & 0 & 0 & 3.0 & Most Preferred \\
\hline Pune & 31 & 69 & 0 & 2.3 & Preferred \\
\hline Trichy & 29 & 71 & 0 & 2.3 & Preferred \\
\hline
\end{tabular}

Fig 5: Significance of Tier 2 and Tier 3 towns

This finding has been corroborated from figure 5 where it can be seen that all the respondents prefer expansion in tier 2 and tier 3 towns rather than in tier 1 towns such as Delhi and Mumbai.

\begin{tabular}{|c|c|c|c|c|c|}
\hline & $\begin{array}{c}\text { Most } \\
\text { Preferred } \\
3\end{array}$ & Preferred & $\begin{array}{c}\text { Not } \\
\text { Preferred } \\
1\end{array}$ & $\begin{array}{l}\text { Weighted } \\
\text { Average }\end{array}$ & Interpretation \\
\hline $\begin{array}{l}\text { Less traffic, less crowd } \\
\text { and less pollution }\end{array}$ & 96 & 4 & 0 & 3.0 & Most Important \\
\hline $\begin{array}{l}\text { Closer proximity to } \\
\text { tourist centres }\end{array}$ & 11 & 89 & 0 & 2.1 & Important \\
\hline $\begin{array}{l}\text { More potential for } \\
\text { dining business }\end{array}$ & 91 & 9 & 0 & 2.9 & Most Important \\
\hline Cheaper costs & 93 & 7 & 0 & 2.9 & Most Important \\
\hline Good infrastructure & 96 & 4 & 0 & 3.0 & Most Important \\
\hline $\begin{array}{l}\text { Proximity to religious } \\
\text { places/pilgrimage } \\
\text { spots }\end{array}$ & 0 & 100 & 0 & 2.0 & Important \\
\hline $\begin{array}{l}\text { More peaceful and } \\
\text { quiet }\end{array}$ & 100 & 0 & 0 & 3.0 & Most Important \\
\hline
\end{tabular}

Fig 6: Significance of Tier 2 and Tier 3 towns

The manifold attractions of smaller towns have been captured in figure 6 where the findings are all in line with those of the literature review on the potential of these towns for growth and development of hospitality sector.

The respondents were also queried on what type of lodging formats they believed hold most potential for the development of the hospitality sector in India. Figure 7 summarizes the results of the respondents. 


\begin{tabular}{|l|c|c|c|c|l|}
\hline & Most Preferred & Preferred & Not Preferred & $\begin{array}{c}\text { Weighted } \\
\text { Average }\end{array}$ & Interpretation \\
\cline { 2 - 4 } & 3 & 2 & 1 & 1.1 & Not Preferred \\
\hline 5 Star hotels & 0 & 8 & 92 & 1.8 & Preferred \\
\hline 4 Star hotels & 0 & 81 & 19 & 2.1 & Preferred \\
\hline 3 Star hotels & 20 & 68 & 12 & 3.0 & Most Preferred \\
\hline Budget hotels & 100 & 0 & 0 & 3.0 & Most Preferred \\
\hline Boutique hotels & 100 & 0 & 0 & 3.0 & Most Preferred \\
\hline Resorts & 100 & 0 & 0 & 3.0 & Most Preferred \\
\hline Jungle Lodges & 100 & 0 & 0 & & \\
\hline
\end{tabular}

Fig 7: Potential of Lodging Formats

It can be seen that the most preferred formats induce budget hotels, boutique hotels, resorts and jungle lodges. The 5 star formats are universally regarded as having attained saturation in terms of capacity and in terms of their ability to attract tourists. The smaller formats, whilst being closer to centres of attraction in the country are also relatively lower priced which means that travelling becomes more affordable. This in turn increases tourist traffic. Figure 8 summarizes the reasons why tourists believe budget hotels have more potential as compared to luxury hotel formats in the country.

\begin{tabular}{|c|c|c|c|c|c|}
\hline & $\begin{array}{c}\text { Most } \\
\text { Preferred } \\
3\end{array}$ & Preferred & $\begin{array}{c}\begin{array}{c}\text { Not } \\
\text { Preferred }\end{array} \\
1\end{array}$ & $\begin{array}{l}\text { Weighted } \\
\text { Average }\end{array}$ & Interpretation \\
\hline Less costs & 0 & 8 & 92 & 1.1 & Most Preferred \\
\hline $\begin{array}{l}\text { More practical for } \\
\text { budget conscious } \\
\text { tourists }\end{array}$ & 0 & 81 & 19 & 1.8 & Most Preferred \\
\hline $\begin{array}{l}\text { Budget hotels give } \\
\text { almost the same } \\
\text { amenities as luxury } \\
\text { hotels }\end{array}$ & 20 & 68 & 12 & 2.1 & Most Preferred \\
\hline $\begin{array}{l}\text { The customer service in } \\
\text { budget hotels is on part } \\
\text { with that of luxury } \\
\text { hotels }\end{array}$ & 100 & 0 & 0 & 3.0 & Most Preferred \\
\hline $\begin{array}{l}\text { Budget hotels are as } \\
\text { good as luxury hotels } \\
\text { minus any unnecessary } \\
\text { frills }\end{array}$ & 100 & 0 & 0 & 3.0 & Most Preferred \\
\hline $\begin{array}{l}\text { I believe luxury hotels } \\
\text { are over priced }\end{array}$ & 100 & 0 & 0 & 3.0 & Most Preferred \\
\hline $\begin{array}{l}\text { Budget hotels have } \\
\text { adequate business } \\
\text { facilities }\end{array}$ & 100 & 0 & 0 & 3.0 & Most Preferred \\
\hline
\end{tabular}

Fig 8: The attractiveness of budget hotels vis-a-vis luxury hotels 
It can be seen from figure 8 that respondents believe there is little differentiation between luxury hotels and budget hotels in terms of customer service, facilities and amenities offered. At the same time there is a big difference in pricing with budget hotels being far more affordable. Hence the emergence of budget hotels is another key trend that is expected to dominate the hospitality sector in India over the next decade.

\section{Conclusion}

The main purpose of this paper was to validate the theoretical findings that while the Indian hospitality sector exhibits huge potential for growth and development, this has to be balanced against many challenges. These theoretical findings have all been corroborated with the findings of the questionnaire. It may be inferred therefore that a bright future awaits the hospitality sector in India with several key, new themes slated to emerge and dominate over the next decade. These include the growth of domestic tourism vis a vis foreign tourists, the predominance of medical tourism over other forms of tourism, the development of business tourism which is treated on par if not more important than leisure tourism, the growing importance of tier 2 and tier 3 towns, and the metamorphosis of budget / mid - level hotels vis a vis the luxury formats. However, the ability of the hospitality sector to take advantage of these developments is contingent on the successful countering of such challenges as government bureaucracy, high prices, and cost of operations, high attrition rates, lack of skilled manpower and the lack of infrastructure. It is these challenges that are the hurdles in the further development of the Indian hospitality sector in comparison with other tourist destinations such as Singapore and the UK.

Based on the findings of this report, the following recommendations have been made:

The hospitality sector must consider making investments in tier 2 and tier 3 cities of India.

Rather than invest in expensive five star properties, it would make more business sense to invest in mid-level and budget hotels. At 
cultural / religious / architectural destinations it would be wise to invest in low cost resort facilities.

The hotels must include such facilities as conference rooms, video conferencing / teleconferencing / meeting rooms / board rooms / $\mathrm{WiFi}$ and all those facilities that cater to the needs and requirements of business travelers

As far as possible, the hotels must make attempts to woo domestic customers as well rather than focusing only on foreign tourists.

The hotels sector must include sustainable and environment friendly practices in their buildings and in their operations.

The hospitality and tourist sector must come together to leverage their clout and apply pressure on the government to improve infrastructure, reduce taxes and provide more facilities and incentives for the development of the hospitality sector. Of particular note here is easing visa norms for foreign tourists which are currently quite stringent.

The hospitality sector must put in place training and development programs as well as best practice retention programs to improve skills of staff and reduce attrition rates as well. Every effort must be made to incorporate international best practices in aspects such as customer service in the training programs being implemented for hotel staff.

\section{Reference}

Adner, R. (2010).Lifestyles of the Rich and Almost Famous. New York: McGraw\& Hill.

Barot, K. (2011).Indian Hotel Industry Survey: Amravati. New Delhi, India : FHRAI.

Beech, J., \& Chadwick, S. (2012).The Business of Tourism Management. Pearson Education Ltd.

Berry, P. (2010).Trends in the Indian Hospitality Industry. Oxford, UK: Butterworth - Heinemann.

Gee, C. (2011).International Hotels: Development and Management. East Lansing: Educational Institute of the American Hotel and Motel Association. 
Gibson, D. (2012). Hotel controllers in the 21st century - A perspective on desired attributes. International Journal of Hospitality Management, 23, 485-503.

Gill, A.K., \& Gill, S.S. (2012).Quality of Service in the Hospitality Industry. World Review of Business Research, 2(3), 1 - 12.

Jogaratnam, G., \& Tse, E. (2011). Entrepreneurial orientation and the structuring of organizations Performance evidence from the Asian hotel industry. International Journal of Contemporary Hospitality Management, 18, 66 - 75.

Krishnan, L. (2010). Hotels face host of challenges. The Business of Tourism (7th ed.). Prentice Hall, Financial Times.

Kulins, L. (2011).Most Favoured Hotel Destinations. New York: A.T. Kearney Publications.

Marothia, R. (2010). Indian Hotel Industry Survey. New Delhi, India: FHRAI.

Page, S. J. (2011) Tourism Management - Managing for change in India. New York: Butterworth- Heinemann.

Parasuraman, A., Zeithaml, V.A., \& Berry L.L. (1994). SERVQUAL: A multiple item scale for measuring consumer perceptions of service quality. Journal of Retailing, 64, 1240 - 1260.

Rathod, A., Kasera, R., \& Khan, S. (2013).Hotel Industry in India. New Delhi : Acer Press.

Thadani, M. (2012).Critical Issues Facing Indian Hospitality. Gurgaon, India: HVS Hospitality Services. 